\title{
Diagnosis of Growth Hormone Deficiency: the role of Growth Hormone (GH), Insulin- Like Growth Factor (IGF-I) and IGF-Binding Protein (IGFBP-3)
}

\author{
Abdullah Bereket \\ Marmara University Medical School, Pediatric Endocrinology Department, Istanbul, Turkey
}

Keywords:
Growth hormone, growth
hormone deficiency,
insulin-like growth factor I,
insulin-like growth
factor-binding protein 3,
IGF-I, IGFBP-3
Received: 09 October, 2008
Accepted: 22 October, 2008
Corresponding Author:
Abdullah Bereket
Marmara University Medical
School, Pediatric
Endocrinology Department,
Istanbul, Turkey
E-mail:
abereket@e-kolay.net

\section{Keywords:}

Growth hormone, growt

hormone deficiency,

insulin-like growth

factor-binding protein 3

Received: 09 October, 2008

Corresponding Author:

Abdullah Bereket

Marmara University Medical

Istanbul, Turkey

abereket@e-kolay.net

\section{SUPPLEMENT}

\begin{abstract}
Despite dramatic changes in the treatment of growth hormone $(\mathrm{GH})$ deficiency from cadaveric pituitary growth hormone to recombinant human growth hormone, the diagnosis of idiopathic growth hormone deficiency remains a challenge for the clinician. The uncertanities in the cut-off values to describe growth hormone deficiency and reference data for growth hormone secretion in normally growing children, differences in growth hormone assays over the time, problems in reproducibility of growth hormone test results all contribute to this vagueness. However, diagnosing growth hormone deficiency is important to identify children who will benefit most from the GH treatment. GH dependent peptides, insulin-like growth factor I (IGF-I) and insulin-like growth factor-binding protein 3, (IGFBP-3) are good markers of growth hormone status and are useful in diagnosing GH deficiency as well as monitoring efficacy of growth hormone treatment. An overview of problems in the diagnosis of GH deficiency and the role of IGF-I and IGFBP-3 in the diagnosis of GH deficiency is provided in this paper.

Conflict of interest: None declared
\end{abstract}

Since numerous reasons other than GH deficiency can cause growth retardation, the diagnosis of $\mathrm{GH}$ deficiency in a child with short stature should never be based solely on auxological or solely on biochemical-hormonal criteria. The diagnosis should be reached by a critical evaluation of all the relevant data brought together. In fact, even the normal limits for GH response to stimulation tests for endogenous $\mathrm{GH}$ secretion have not yet been fully standardised and this response is known to be influenced by factors like age, sex, pubertal stage and body mass index. Problems with the diagnosis of growth hormone deficency based on GH measurements alone are as follows:

1. The established approach to the diagnosis of GH deficiency is based on the assumption that $\mathrm{GH}$ deficient children have a lower GH response to stimulation compared to that of normally growing children. However, many studies have shown that the maximal response in normal children can remain below 10, 7 or even under $5 \mu \mathrm{g} / \mathrm{L}$. Differences in methods used for measurement of GH in biological materials, interlaboratory differences in cutoff values for normal ranges arising from differences in methodology, difficulties inherent in the use of physio- 
logical stimulation tests as well as the multiplicity of agents used for pharmacological stimulation and the non-standardised use of sex steroids prior to the testing, all contribute to the present inadequacies of the diagnostic criteria.(1, 2, 3, 4)

2. Even if we all agree on a cut-off value, reproducibility of $\mathrm{GH}$ response on $\mathrm{GH}$ stimulation testing is poor. A significantly large proportion of the so-called GH deficient patients demonstrate normal response to $\mathrm{GH}$ re-testing after the completion of the treatment. In $25-44 \%$ of the individuals with the diagnosis of GH deficiency during childhood found to have normal GH levels on spontaneous GH secretion during sleep or on pharmacological testing when retested at adulthood. $(5,6)$

3. Another area of imprecision comes from the question of conditions where the normalcy of GH secretion is evaluated (spontaneous vs stimulated). Although the best approach is considered to be the assessment of the spontaneous GH release, the difficulties associated with technicalities and the standardisation of the results in this method as well as the costs, have restricted its application to research procedures only. $(7,8)$

4. GH estimation in the body fluids is presently carried out by a variety of methods made available with commercial kits. These methods include radioimmunoassay (RIA) which utilizes polyclonal antibodies or enzyme-linked immunoabsorbant assay, immunoradiometric assay and ligand immunofunctional assay, all of which utilise monoclonal antibodies. A GH standard of $2 \mathrm{IU} / \mathrm{mg}$, derived from hypophyseal tissue and made available by the 'National Hormone and Pituitary Program' (USA), used in the earlier stages of laboratory measurement of $\mathrm{GH}$ was later replaced by another standard of 2.6 $\mathrm{IU} / \mathrm{mg}$, also of hypophysial origin and coded as IRP 80/505. In 1998, WHO recommended the use of recombinant 22kDa hGH (human GH), coded 88/624, of $3 \mathrm{IU} / \mathrm{mg}$ strength, and inclusion of this standard material in the kits presented to the market by the industry.(1,2)

Although these new assays have provided sensitivity, speed, cost reduction and the facility of automisation, they have also brought the endocrinologist face to face with a number of problems. The use of polyclonal antibodies enabled the detection of all immunogenic epitopes of GH in the circulation, while the more recent assay kits with monoclonal antibodies, which do not recognise all components of $\mathrm{GH}$ in the circulation, give lower results for $\mathrm{GH}$ levels and necessitate the establishment of new and lower cutoff (threshold) values. For example, the previously accepted threshold of 5-7 $\mu \mathrm{g} / \mathrm{L}$ should now become $<5 \mu \mathrm{g} / \mathrm{L}$. However, exactly the opposite has been recommended and the threshold has been raised to $10 \mu \mathrm{g} / \mathrm{L}$. We believe this is an error and should be corrected. The new assays should be assessed on samples from normally growing children to establish the appropriate threshold levels.

Various pharmacological agents are being used for GH stimulation tests. The sensitivity of these tests is low.(4) The results obtained with these pharmacological agents on healthy children of normal or subnormal height, using $7 \mu \mathrm{g} / \mathrm{L}$ and $10 \mu \mathrm{g} / \mathrm{L}$ as the lower limits of normal are shown in Table 1. The figures indicate the proportion of healthy children which show values under these cutoff limits. When the lower limit for GH deficiency is taken as $7.5 \mu \mathrm{g} / \mathrm{L}$, the sensitivity is calculated as $73 \%$, the specificity $83 \%$, and the positive predictive value is $50 \%$.

Stimulation of GH secretion with sex steroids: The physiological decrease in $\mathrm{GH}$ secretion just before puberty causes difficulty in differentiating this physiological event from GH deficiency. Therefore, exogenous sex steroids has been recommended to be used as a priming tool prior to the stimulation tests.(9) Priming with sex steroids can be done at age 10 in prepubertal girls and at age 12 in prepubertal boys. The use of ethynyl oestradiol can be recommended in both sexes at a single dose of $20-40 \mu \mathrm{g} / \mathrm{day}$, given the night before 
Table 1: GH response to pharmacological stimulation in healthy children of normal and subnormal height, calculated with $7 \mu \mathrm{g} / \mathrm{L}$ and $<10 \mu \mathrm{g} / \mathrm{L}$ as cut-off limits. ${ }^{4}$

\begin{tabular}{lcccc}
\hline Pharmacological agent & Max (min) & Mean (range) & $<7 \boldsymbol{\mu g} / \mathbf{L}$ & $<\mathbf{\mu g} / \mathbf{L}$ \\
Pyridostigmin & 60 & $13.5(2.5-35)$ & $15 \%$ & $36 \%$ \\
Insulin & 90 & $13.2(2.7-46)$ & $23.7 \%$ & $49.1 \%$ \\
Arginine & 45 & $16.7(4.4-45.5)$ & $12.6 \%$ & $32.9 \%$ \\
Clonidine & 60 & $13.1(4.5-56.5)$ & $10.1 \%$ & $23.2 \%$ \\
L-Dopa & 45 & $13(1.9-40)$ & $23.6 \%$ & $10 \%$ \\
Glucagon & 120 & $16.9(1.9-49.5)$ & $8.9 \%$ & $35 \%$ \\
GHRH & 30 & $28.8(2.7-102)$ & 0 & $14.9 \%$ \\
Pyridostigmin+GHRH & 30 & $47(19-106)$ & 0 & 0 \\
Arginine+GHRH & 45 & $61(19-120)$ & & 0 \\
GHRH: GH releasing hormone; Max: maximum & & & 0
\end{tabular}

the test. An alternative approach would be to administer $20 \mu \mathrm{g} /$ day $\times 3$ days ethynyl oestradiol in girls, and $100 \mathrm{mg}$ i.m. testosterone enanthate in boys in one dose three days before the test. However, a consensus has not been reached regarding the use of exogenous sex steroids or the age at which they should be given. More data especially on final height is needed to clarify whether priming is helpful in differentiating those children who are not "really GH deficient" and therefore will not benefit from GH treatment.

\section{WHICH PATIENTS SHOLUD BE TESTED?}

For the clinical diagnosis of GH deficiency, after the elimination of skeletal dysplasias, genetic diseases such as Turner syndrome, other endocrinopathies, any chronic or systemic condition that might explain shortness or growth retardation, the history, physical findings and auxological data given below can be taken as signs of GH deficiency.(1)

\section{Clinical findings suggestive of GH deficiency}

Presence of (1) a family history of GH deficiency or of close consanguinity between the parents; (2) a history of perinatal trauma or of hypoglycemia, prolonged jaundice, micropenis in the newborn period; (3) anomalies such as the midline defects; (4) a history of cranial irradiation, intracranial lesions, head trauma, central nervous system infections and multiple hypophyseal hormone deficiency, have been agreed upon to be suggestive of GH deficiency.

\section{Auxological findings suggestive of GH deficiency}

Auxological findings accepted by the Growth Hormone Society (GHS) and the European Society of Paediatric Endocrinology (ESPE) as suggestive of a diagnosis of GH deficiency and which need to be confirmed by further investigation include:

1. Extreme shortness (height for age $<-3$ SD) without an explanatory reason

2. Medium shortness (height for age between -2 SD and -3 SD) with

a) a growth velocity less than $25^{\text {th }}$ percentile or, in children $>2$ years of age, a decrease of $>0.5$ SDS in height noted after one year of follow-up

b) a predicted height value lower than the target height by 1.5 SD (approximately $9-10 \mathrm{~cm}$ )

3. Without shortness of stature, a slow growth velocity of $(<2 \mathrm{SD}$ or $<5$ p) over 1 year or of $<1.5$ SD over two years.

\section{Estimation of target height}

There are two equations which can be used for this calculation:

1. Target Height for Boys $=($ Mother's Height+Father's Height $) / 2+6.5$ Target Height for Girls = (Mother's Height+Father's Height $) / 2-6.5$

2. Midparental Height SDS $=$ (Mother's Height SDS+Father's Height SDS $) / 1.6$ 


\section{DIAGNOSIS OF GH DEFICIENCY IN THE NEWBORN}

In both preterm and term newborns, GH levels in the first days of life are $>20$ $\mu \mathrm{g} / \mathrm{L} .^{10-11}$ IGF-I values, are relatively low, but it has been shown that in infancy, IGF-I values lower than -2 SD for age are suggestive of GH deficiency. In newborns with micropenis, hypoglycemia, birth trauma or a family history of GH deficiency, a value of $20 \mu \mathrm{g} / \mathrm{L}$ or below by routine $\mathrm{GH}$ estimation (using polyclonal antibodies) can be accepted as indicative of GH deficiency.

\section{IGF-I AND IGFBP-3 IN GH DEFICIENCY}

\section{Changes in the levels of growth factors with age}

In healthy children serum IGF-I and IGFBP-3 levels well reflect the endogenous 24-hour GH secretion. These levels have been recognised as useful clinical parameters since they show very little diurnal change and remain stable.(12, 13, 14, 15, 16, 17, 18, 19)

Insulin and IGF-I are the two main factors responsible for growth in the early postnatal period. Studies have shown that birth weight, placental weight and gestational age correlate positively with the cord blood IGF-I levels. In preterms, cord blood IGF-I, IGFBP-3 and the acid-labile subunit (ALS) levels are lower than in term newborns. (10, 20, 21)

In the early neonatal period, serum IGF-I levels are closely associated with nutritional state. This association weakens but remains through childhood and adulthood. The levels fall during periods of inadequate nutrition and rise with reversion to normal nutrition.(22)

The fundamental factors influencing growth are nutrition during the infancy period, primarily GH and also other hormones during childhood, and in addition to these, sex steroids during the pubertal period. In late infancy and early childhood, serum IGF-I and IGFBP-3 levels become GH dependent.

The relatively low serum IGF-I and IGFBP-3 levels at birth start increasing during childhood and reach maximal levels in adolescence and fall thereafter to prepubertal levels in adulthood.(23)

During childhood IGF-I levels increase slowly and show each year a parallelism with the growth rate of the following year. $(23,24)$ Longitudinal studies have shown that serum IGF-levels maintain this parallelism until the attainment of the maximal growth velocity. Thereafter, despite the fall in postpubertal growth rate, IGF-I levels have been observed to remain high. Therefore, the correlation between the IGFI levels and the growth rate is marked only in prepubertal children. $(25,26)$

In both sexes, the increase in sex steroids during puberty results in higher $\mathrm{GH}$ secretion. Alongside with this increase in GH secretion, an increase in GH sensitivity also contributes to the increase in IGF-I and IGFBP-3 levels.(13) Peak IGF-I and IGFBP-3 levels are reached approximately 2 years after the attainment of peak height velocity. $(27,28)$

Although serum IGF-I and IGFBP-3 determinations are very useful in evaluating growth disorders, a reliable normative data is needed for optimal benefit of these diagnostic tools. Since IGF-I levels vary with age, sex and puberty, a large sample is needed to determine normative values. There are differences in reported reference values for normal ranges due to differences in populations studied and differences in assay methods used. Values obtained in a study using the immunoradiometric assay (IRMA) method (DSL assay kits) carried out on healthy school children in Istanbul in order to determine the reference range for IGF-I levels in Turkey are presented in Tables 2-7 and Figures 2-5 below. These data have made possible the calculation of IGF-I SDS and IGFBP-3 SDS values. $(28,29)$ 
Table 2: Change in serum mean, standard deviation (SD) and standard deviation score (SDS) IGF-I levels in healthy girls with age.

\begin{tabular}{|c|c|c|c|c|c|c|c|c|}
\hline \multirow[b]{3}{*}{ Age } & \multirow[b]{3}{*}{$\mathrm{N}$} & \multicolumn{2}{|c|}{ IGF-I( $\left(^{*}\right)$} & \multicolumn{5}{|c|}{ IGF-I } \\
\hline & & & & \multicolumn{2}{|c|}{ SD } & & \multicolumn{2}{|c|}{ SD } \\
\hline & & Mean & SD & -1 & 1 & Mean & -2 & 2 \\
\hline 4 & 17 & 11.7 & 3.2 & 75 & 220 & 140 & 30 & 330 \\
\hline 5 & 6 & 13.8 & 3.7 & 110 & 280 & 180 & 50 & 400 \\
\hline 6 & 17 & 15.3 & 2.1 & 140 & 340 & 225 & 70 & 480 \\
\hline 7 & 28 & 15.8 & 3.9 & 170 & 390 & 270 & 90 & 545 \\
\hline 8 & 41 & 17.2 & 3.8 & 210 & 455 & 320 & 120 & 620 \\
\hline 9 & 30 & 18.5 & 3.4 & 260 & 520 & 370 & 160 & 680 \\
\hline 10 & 33 & 20.3 & 3.7 & 320 & 580 & 430 & 220 & 740 \\
\hline 11 & 46 & 23.1 & 3.2 & 380 & 630 & 500 & 280 & 780 \\
\hline 12 & 32 & 24.0 & 1.6 & 440 & 670 & 545 & 340 & 805 \\
\hline 13 & 39 & 24.1 & 1.9 & 470 & 690 & 580 & 380 & 820 \\
\hline 14 & 31 & 24.5 & 2.1 & 485 & 705 & 590 & 390 & 830 \\
\hline 15 & 24 & 24.1 & 2.8 & 480 & 700 & 585 & 385 & 830 \\
\hline 16 & 28 & 24.1 & 2.7 & 465 & 680 & 580 & 375 & 805 \\
\hline 17 & 7 & 23.0 & 1.7 & 455 & 640 & 545 & 360 & 750 \\
\hline
\end{tabular}

Table 3: Change in serum mean, standard deviation (SD) and standard deviation score (SDS) IGF-I levels in healthy boys with age.

\begin{tabular}{|c|c|c|c|c|c|c|c|c|}
\hline \multirow[b]{3}{*}{ Age } & \multirow[b]{3}{*}{$\mathrm{N}$} & \multicolumn{2}{|c|}{ IGF-I( $\left(^{*}\right)$} & \multicolumn{5}{|c|}{ IGF-I } \\
\hline & & & & \multicolumn{2}{|c|}{ SD } & & \multicolumn{2}{|c|}{ SD } \\
\hline & & Mean & SD & -1 & 1 & Mean & -2 & 2 \\
\hline 4 & 20 & 10.0 & 3.2 & 50 & 180 & 100 & 15 & 270 \\
\hline 5 & 7 & 11.2 & 3.4 & 70 & 220 & 130 & 30 & 325 \\
\hline 6 & 19 & 13.9 & 3.2 & 100 & 260 & 170 & 45 & 380 \\
\hline 7 & 25 & 14.5 & 3.2 & 120 & 300 & 200 & 60 & 420 \\
\hline 8 & 28 & 15.7 & 2.3 & 140 & 340 & 230 & 70 & 480 \\
\hline 9 & 39 & 15.4 & 4.0 & 160 & 380 & 260 & 80 & 540 \\
\hline 10 & 41 & 16.6 & 3.1 & 190 & 440 & 300 & 100 & 610 \\
\hline 11 & 37 & 18.5 & 4.3 & 230 & 510 & 350 & 130 & 700 \\
\hline 12 & 31 & 19.6 & 4.7 & 280 & 580 & 415 & 180 & 780 \\
\hline 13 & 38 & 22.9 & 2.5 & 340 & 640 & 480 & 240 & 830 \\
\hline 14 & 48 & 24.1 & 3.2 & 405 & 700 & 540 & 290 & 880 \\
\hline 15 & 41 & 25.1 & 2.9 & 450 & 740 & 580 & 330 & 910 \\
\hline 16 & 26 & 25.0 & 2.8 & 470 & 750 & 600 & 350 & 910 \\
\hline 17 & 28 & 23.7 & 2.8 & 475 & 740 & 600 & 355 & 890 \\
\hline
\end{tabular}

\section{THE DIAGNOSTIC SIGNIFICANCE OF IGF-I AND IGFBP-3}

In the diagnosis of GH deficiency

The conditions which affect the GH-IGF axis and the relative changes of serum $\mathrm{GH}$, IGF-I ve IGFBP-3 levels are given in Table 8.

Low IGF-I levels in GH deficiency have been shown in many studies. While IGF-I levels were found to be lower than -2 SD 
Table 4: Change in serum mean, standard deviation (SD) and standard deviation score (SDS) of IGFBP-3 levels in healthy girls with age.

\begin{tabular}{|c|c|c|c|c|c|c|c|c|}
\hline \multirow[b]{3}{*}{ Age } & \multirow[b]{3}{*}{$\mathrm{N}$} & \multicolumn{2}{|c|}{ IGFBP-3 } & \multicolumn{5}{|c|}{ IGFBP-3 } \\
\hline & & & & \multicolumn{2}{|c|}{ SD } & & \multicolumn{2}{|c|}{ SD } \\
\hline & & Mean & SD & -1 & 1 & Mean & -2 & 2 \\
\hline 4 & 14 & 4291 & 457 & 3650 & 5000 & 4300 & 2950 & 5650 \\
\hline 5 & 6 & 4635 & 1157 & 3750 & 5350 & 4550 & 2950 & 6150 \\
\hline 6 & 16 & 4654 & 806 & 3900 & 5600 & 4750 & 3050 & 6400 \\
\hline 7 & 25 & 4917 & 793 & 4100 & 5750 & 4950 & 3250 & 6600 \\
\hline 8 & 37 & 5150 & 860 & 4300 & 5950 & 5100 & 3450 & 6750 \\
\hline 9 & 31 & 5062 & 758 & 4500 & 6150 & 5300 & 3700 & 6950 \\
\hline 10 & 33 & 5505 & 821 & 4700 & 6350 & 5500 & 3950 & 7200 \\
\hline 11 & 45 & 5763 & 793 & 4900 & 6450 & 5700 & 4150 & 7250 \\
\hline 12 & 30 & 5916 & 659 & 5050 & 6550 & 5800 & 4300 & 7350 \\
\hline 13 & 37 & 6047 & 778 & 5100 & 6600 & 5850 & 4350 & 7350 \\
\hline 14 & 30 & 5580 & 779 & 5050 & 6550 & 5800 & 4350 & 7300 \\
\hline 15 & 29 & 5863 & 822 & 5000 & 6400 & 5700 & 4350 & 7100 \\
\hline 16 & 28 & 5455 & 523 & 4900 & 6150 & 5550 & 4350 & 6800 \\
\hline 17 & 11 & 5346 & 539 & 4800 & 5900 & 5350 & 4350 & 6400 \\
\hline
\end{tabular}

Table 5: Change in serum mean, standard deviation (SD) and standard deviation score (SDS) IGFBP-3 levels in healthy boys with age.

\begin{tabular}{|c|c|c|c|c|c|c|c|c|}
\hline \multirow[b]{3}{*}{ Age } & \multirow[b]{3}{*}{$\mathrm{N}$} & \multicolumn{2}{|c|}{ IGFBP-3 } & \multicolumn{5}{|c|}{ IGFBP-3 } \\
\hline & & & & \multicolumn{2}{|c|}{ SD } & & \multicolumn{2}{|c|}{ SD } \\
\hline & & Mean & SD & -1 & 1 & Mean & -2 & 2 \\
\hline 4 & 20 & 4040 & 755 & 3550 & 4700 & 4100 & 2950 & 5300 \\
\hline 5 & 8 & 4557 & 315 & 3600 & 4900 & 4250 & 2950 & 5600 \\
\hline 6 & 16 & 4208 & 870 & 3650 & 5150 & 4400 & 2900 & 5900 \\
\hline 7 & 22 & 4417 & 886 & 3700 & 5350 & 4550 & 2900 & 6200 \\
\hline 8 & 26 & 4547 & 927 & 3850 & 5600 & 4750 & 3000 & 6500 \\
\hline 9 & 34 & 4971 & 805 & 4100 & 5850 & 4950 & 3200 & 6750 \\
\hline 10 & 39 & 5141 & 927 & 4350 & 6100 & 5225 & 3400 & 7000 \\
\hline 11 & 37 & 5578 & 910 & 4550 & 6350 & 5450 & 3650 & 7200 \\
\hline 12 & 29 & 5631 & 925 & 4700 & 6450 & 5600 & 3850 & 7350 \\
\hline 13 & 36 & 5932 & 686 & 4800 & 6550 & 5700 & 4000 & 7350 \\
\hline 14 & 44 & 5617 & 807 & 4900 & 6450 & 5650 & 4050 & 7300 \\
\hline 15 & 35 & 5566 & 952 & 4750 & 6350 & 5575 & 4000 & 7150 \\
\hline 16 & 26 & 5294 & 623 & 4650 & 6200 & 5490 & 3950 & 6950 \\
\hline 17 & 29 & 5348 & 745 & 4550 & 6000 & 5450 & 3850 & 6700 \\
\hline
\end{tabular}

of the mean value for respective age in $82 \%$ of patients with GH deficiency, these values were found to be within normal limits in $68 \%$ of short children with no GH deficiency.(30) In 203 boys of low stature, Juul et al.(31) have found that IGF- I values of 2 SD below the mean had a positive pre- dictive value of $57 \%$. In children younger than 10 years, IGF-I estimation is more useful than estimation of $\mathrm{GH}$ in pointing to subnormality in GH stimulation tests (Figure 13). An IGF-I value of -2.5 SD gives the optimal limit for discriminating $\mathrm{GH}$ deficiency from idiopathic low stature.(31) 
Table 6: Calculation of IGF-I z-score (SDS) according to the Tanner scoring.

\begin{tabular}{|c|c|c|c|c|c|c|}
\hline Tanner Score & $\alpha(\mathrm{SE})$ & $\beta(\mathrm{SE})$ & SD & $P$ & $N$ & $r$ \\
\hline \multicolumn{7}{|c|}{ Boys } \\
\hline I & $7.94(0.997)$ & $0.82(0.108)$ & 3.95 & $<0.0001$ & 198 & 0.479 \\
\hline II & $14.53(4.642)$ & $0.44(0.381)$ & 3.12 & 0.258 & 32 & 0.206 \\
\hline III & $7.96(6.692)$ & $1.01(0.507)$ & 3.66 & 0.058 & 25 & 0.384 \\
\hline IV & $25.40(5.599)$ & $-0.07(0.396)$ & 2.68 & 0.858 & 41 & -0.029 \\
\hline $\mathrm{V}$ & $27.08(3.119)$ & $-0.16(0.197)$ & 2.64 & 0.428 & 113 & -0.075 \\
\hline \multicolumn{7}{|c|}{ Girls } \\
\hline I & $8.09(1.101)$ & $1.0(0.143)$ & 3.75 & $<0.0001$ & 123 & 0.536 \\
\hline II & $14.96(4.764)$ & $0.36(0.464)$ & 3.00 & 0.442 & 21 & 0.177 \\
\hline III & $15.24(4.532)$ & $0.632(0.410)$ & 3.12 & 0.130 & 44 & 0.232 \\
\hline IV & $20.52(2.554)$ & $0.290(0.204)$ & 2.28 & 0.159 & 67 & 0.174 \\
\hline V & $25.96(2.205)$ & $-0.128(0.147)$ & 2.33 & 0.386 & 114 & -0.082 \\
\hline \multicolumn{7}{|c|}{$\begin{array}{l}Y=\beta \times \text { Age (year })+\alpha \\
\text { IGF-I } z \text {-score }=(I G F-1 \text { SQR }-Y) / S D \\
\text { E.g.: } 12 \text { - year old girl; Tanner score III; IGF-I }=400 \mathrm{ng} / \mathrm{mL} \\
\text { VIGF-I }=\text { IGF-I SQR }=20 \\
Y=0.632 \times 12+15.24=22.82 \\
\text { IGF-I } z \text {-score }=(20-22.82) / 3.12=-0.904\end{array}$} \\
\hline
\end{tabular}

Table 7: Calculation of IGFBP-3 Z-Score (SDS) according to Tanner scoring.

\begin{tabular}{|c|c|c|c|c|c|c|}
\hline Tanner Score & $\alpha(\mathrm{SE})$ & $\beta(\mathrm{SE})$ & SD & $P$ & $N$ & $r$ \\
\hline \multicolumn{7}{|c|}{ Boys } \\
\hline I & 3518 (234) & $140(25)$ & 929 & $<0.0001$ & 187 & 0.378 \\
\hline II & $2710(1100)$ & $251(91)$ & 803 & 0.010 & 30 & 0.463 \\
\hline III & 7083 (1354) & $-97(104)$ & 742 & 0.357 & 26 & -0.188 \\
\hline IV & 10934 (1538) & $-352(109)$ & 803 & 0.003 & 35 & -0.489 \\
\hline V & 6926 (939) & $-93(59)$ & 778 & 0.117 & 108 & -0.152 \\
\hline \multicolumn{7}{|c|}{ Girls } \\
\hline I & $3948(318)$ & $111(40)$ & 780 & 0.007 & 114 & 0.250 \\
\hline II & $4216(1371)$ & $133(132)$ & 699 & 0.326 & 20 & 0.231 \\
\hline III & $4100(1076)$ & $129(97)$ & 776 & 0.191 & 44 & 0.201 \\
\hline IV & $7129(816)$ & $-51(65)$ & 801 & 0.429 & 66 & -0.099 \\
\hline $\mathrm{V}$ & 7540 (674) & $-96(45)$ & 717 & 0.033 & 119 & -0.196 \\
\hline \multicolumn{7}{|c|}{$\begin{array}{l}Y=\beta \times \text { Age }(\text { year })+\alpha \\
\text { IGFBP-3 } z \text {-score }=(\text { IGFBP-3 }-Y) / S D \\
\text { E.g.: } 12 \text {-year old boy; Tanner score III; IGFBP-3 }=6000 \mathrm{ng} / \mathrm{mL} \\
Y=-97 \times 12+7083=5919 \\
\text { IGFBP-3 } z \text {-score }=(6000-5919) / 742=0.109\end{array}$} \\
\hline
\end{tabular}

\section{Table 8: Laboratory findings in conditions affecting the GH-IGF axis}

\begin{tabular}{|c|c|c|c|c|}
\hline Condition & GH & IGF-I & IGFBP-3 & Growth \\
\hline GH deficiency & Variable & Low & Low & Decreased \\
\hline GH resistance & Normal/High & Low & Low & Decreased \\
\hline IGF deficiency & Variable & Low & Low/Normal & Decreased \\
\hline Acromegaly & High & High & High & Increased \\
LGA & Variable & High & High & Increased \\
\hline SGA & Low & Low & Low & Decreased \\
\hline LGA: High birth weight for gestational age & & & & \\
\hline SGA: Low birth weight for gestational age & & & & \\
\hline
\end{tabular}


Figure 2: Change in serum IGF-I levels in healthy Turkish girls with age.



\section{Figure 3: Change in serum IGF-I levels of healthy Turkish boys with age}

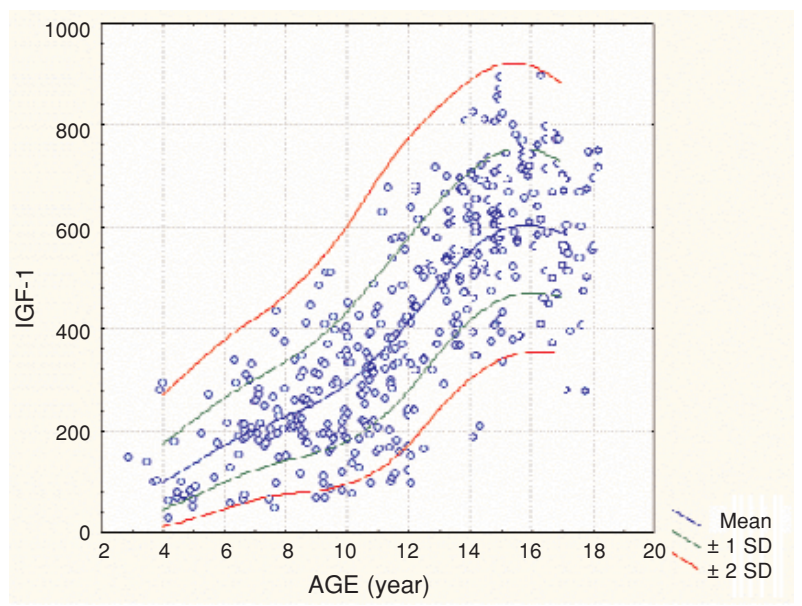

Figure 4: Change in serum IGFBP-3 levels of healthy Turkish girls with age

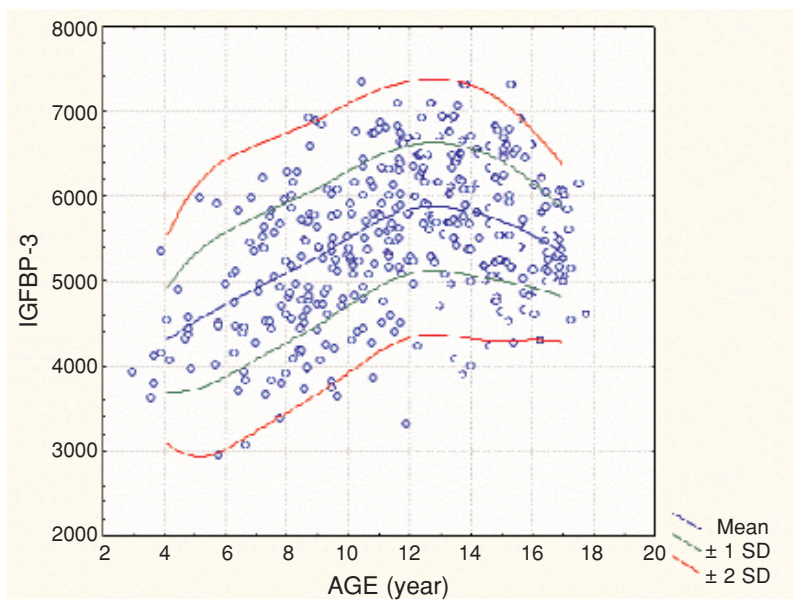

Figure 5: Change in serum IGFBP-3 levels in healthy Turkish boys with age

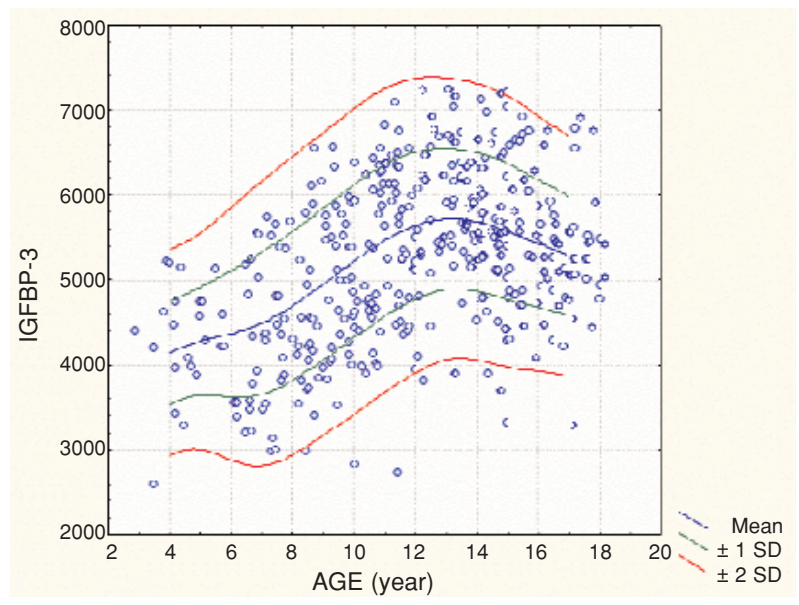

The diagnostic value of estimating IGF-I and IGFBP-3 changes according to the cutoff limits taken, Rikken et al.(32) have demonstrated in a study with 96 children that when a cut-off limit of -0.83 SD was taken for IGF-I, the sensitivity and the specificity of the estimations for detecting $\mathrm{GH}$ deficiency were $92 \%$ and $47 \%$, respectively. If the IGF-I cut-off limit was taken as $-1 \mathrm{SD}$, the percentages of GH deficiency and idiopathic low stature detected became 88 and 46 , respectively. In other studies taking the IGF-I limit at $-2 \mathrm{SD}$, the specificity and the sensitivity of detecting GH deficiency varied between $47 \%$ and $80 \%$ and $61 \%$ and $91 \%$, respectively.(33, 34, 35, 36, 37, 38, 39, 40)

Blum et al. in 1990 have stated that the sensitivity and the specificity of measuring IGFBP-3 were 97\% and 95\%, respectively, and that estimating IGFBP-3 was more useful than measuring IGF-I for the diagnosis of GH deficiency. However, in subsequent studies these high levels of specificity and sensitivity were not demonstrable and the reported sensitivities varied between 15\% and $98 \%$ and the corresponding specificities 
Figure 6: Serum IGF-I values in patients presenting with low stature. The upper panel gives results of GH response to stimulation tests in children with normal GH response and the lower panel gives results on GH deficient children. ${ }^{3}$
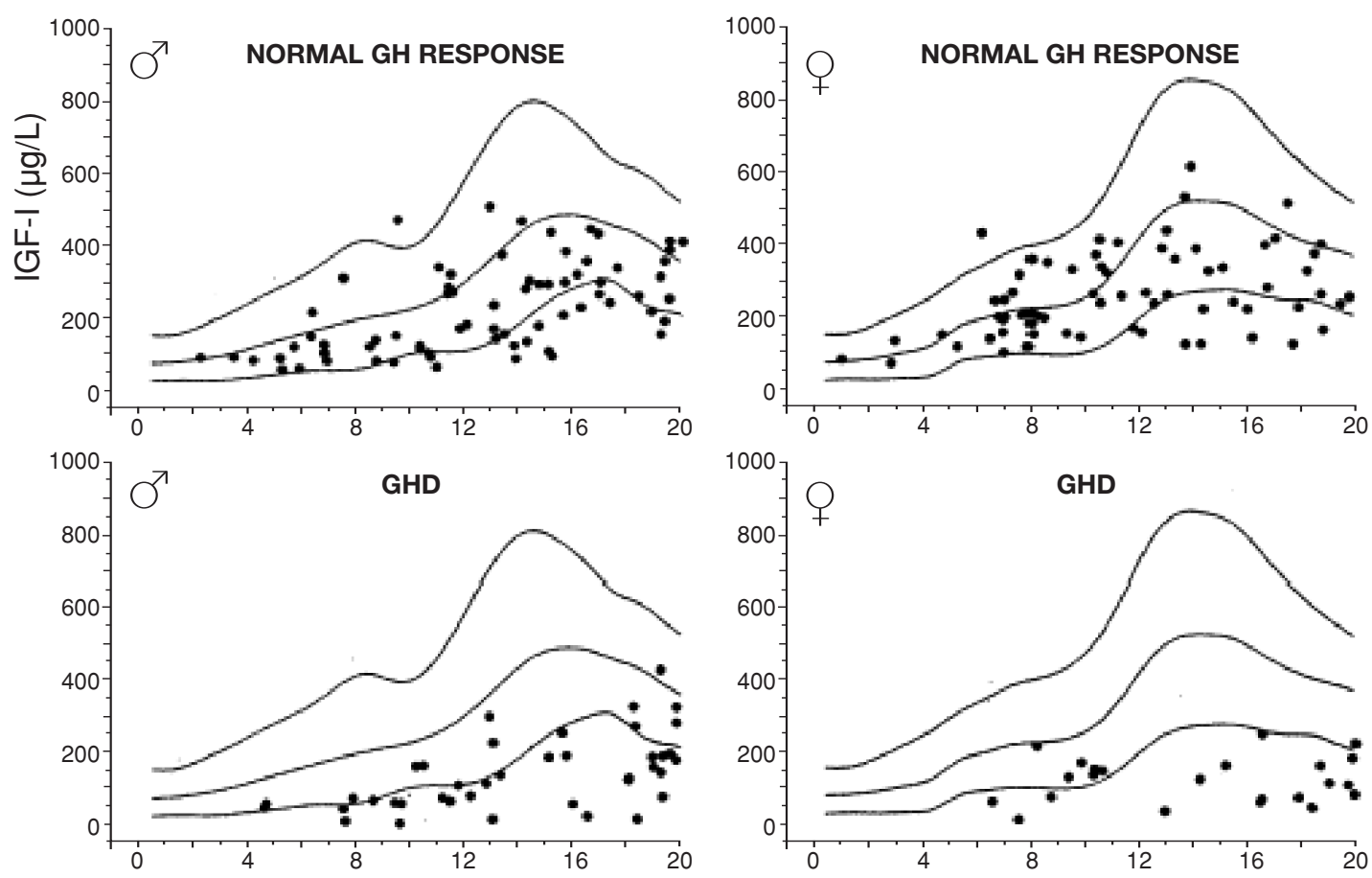

Age (years)

varied between 50\% and 98\%.(42, 43, 44) After the publication of the reference curves for IGF-I and IGFBP-3 values over the age range 0 to 6 years, it was seen that the lower limits of IGF-I levels were very close to the estimated IGF-I values whereas this was not the case with IGFBP-3. Thus, theoretically IGFBP-3 has a diagnostic superiority over IGF-I for the 0 to 6-year age group and this hypothesis has been supported by other studies demonstrating the diagnostic superiority of IGFBP-3 estimations in prepubertal children as compared to those in older children. $(24,31,33)$

In most patients with GH deficiency IGFI and IGFBP-3 levels are low and rise to normal after treatment. IGF-I and IGFBP-3 can be used in evaluation of response to treatment as well as in the follow-up of GH deficient patients, regardless of etiology. The follow up of IGF-I and IGFBP-3 levels theo- retically will help to predict the growth response as well as assessing the efficacy of GH replacement and patient compliance to the treatment. In patients receiving $\mathrm{GH}$ replacement, positive correlations between the z-scores of IGF-I and IGFBP-3 and the increase in height have been shown. In GH replacement dose adjustment IGF-I values specific for age and sex must be taken into consideration.

In recent years, it has been argued that both from the points of view of effectiveness and long term safety, the adjustment of the GH replacement dose be made according to IGF-I and IGFBP-3 values.(45) The advantages and disadvantages of the criteria used in adjusting the $\mathrm{GH}$ replacement dose are shown in Table 10.

The targeted IGF-I z-scores in different stages of the replacement therapy for optimal benefits are shown in Table 11 . 
Table 9: The diagnostic sensivity and specificity of IGF-I ve IGFBP-3 estimations as compared to the results of the GH stimulation tests in children suspected with GH deficiency.

\begin{tabular}{|c|c|c|c|c|c|}
\hline & Age group (yrs) & Stim. test & GH lower limit & Sensitivity & Specificity \\
\hline \multicolumn{6}{|l|}{ IGF-I } \\
\hline Rosenfeld et al. & $1-18$ & ARG+ITT & $7 \mathrm{ng} / \mathrm{ml}$ & $82 \%(56 / 68)$ & $68 \%(30 / 44)$ \\
\hline Lee et al. & $8.9 \pm 4.4$ & CLO, L-DOPA & $7 \mathrm{ng} / \mathrm{ml}$ & $81 \%(13 / 16)$ & $53 \%(71 / 133)$ \\
\hline Blum et al. & $11.2[0.25-34.4]$ & ARG, ITT & $10 \mathrm{ng} / \mathrm{ml}$ & $96 \%(127 / 132)$ & $54 \%(70 / 130)$ \\
\hline Smith et al. & $0.2-18.0$ & ITT, ARG & $1 \mathrm{ng} / \mathrm{ml}$ & $86 \%(49 / 57)$ & $70 \%(16 / 23)$ \\
\hline Cianfarani et al. & $8.1 \pm 1.8$ & ARG, CLO & $8 \mathrm{mU} / \mathrm{l}$ & $69 \%(11 / 16)$ & $80 \%(8 / 10)$ \\
\hline Hasegawa et al. & ND & ARG, ITT & $10 \mathrm{ng} / \mathrm{ml}$ & $88 \%(52 / 59)$ & $79 \%(81 / 103)$ \\
\hline Nunez et al. & $10.7 \pm 2.4$ & ARG, ITT, L-DOPA & $7 \mathrm{ng} / \mathrm{ml}$ & $50 \%(8 / 16)$ & $81 \%(60 / 74)$ \\
\hline Juul and Skakkebæk & 12.7 [1.1-19.9] & ARG, CLO & $15 \mathrm{mU} / \mathrm{l}$ & $69 \%(42 / 61)$ & $77 \%(110 / 142)$ \\
\hline Tillman et al. & $7.9 \pm 3.4$ & Clinical Diagn. * & & $34 \%(20 / 58)$ & $72 \%(78 / 109)$ \\
\hline Rikken et al. & $7.5 \pm 3.5$ & Not known & $20 \mathrm{mU} / \mathrm{l}$ & $61 \%(36 / 59)$ & $78 \%(24 / 32)$ \\
\hline Hall et al. & ND & Not known & $20 \mathrm{mU} / \mathrm{l}$ & $82 \%(18 / 22)$ & $62 \%(29 / 62)$ \\
\hline Mitchell et al. & $0.9-25.4$ & ITT, GLU & $13.5 \mathrm{mU} / \mathrm{l}$ & $62 \%(92 / 148)$ & $47 \%(69 / 147)$ \\
\hline Bussieres et al. & 4.7 [2.9-18.8] & ORN, GLU, AITT & $10 \mathrm{ng} / \mathrm{ml}$ & $84 \%(36 / 43)$ & $57 \%(39 / 68)$ \\
\hline Ranke et al. & $6.8(1.0)$ & AITT & $10 \mathrm{ng} / \mathrm{ml}$ & $75 \%(140 / 187)$ & $50 \%(102 / 205)$ \\
\hline \multicolumn{6}{|l|}{ IGFBP-3 } \\
\hline Blum et al. & $11.2[0.25-34.4]$ & ARG+ITT & $10 \mathrm{ng} / \mathrm{ml}$ & $97 \%(128 / 132)$ & $95 \%(123 / 130)$ \\
\hline Smith et al. & $0.2-18.0$ & ITT, ARG & $1 \mathrm{ng} / \mathrm{ml}$ & $93 \%(53 / 57)$ & $57 \%(13 / 23)$ \\
\hline Hasegawa et al. & ND & ARG, ITT & $5 \mathrm{ng} / \mathrm{ml}$ & $90 \%(53 / 59)$ & $70 \%(71 / 103)$ \\
\hline Cianfarani et al. & $8.1 \pm 1.8$ & ARG, CLO & $8 \mathrm{mU} / \mathrm{l}$ & $50 \%(8 / 16)$ & $90 \%(9 / 10)$ \\
\hline Nunez et al. & $10.7 \pm 2.4$ & ARG, ITT, L-DOPA & $7 \mathrm{ng} / \mathrm{ml}$ & $31 \%(5 / 16)$ & $85 \%(63 / 74)$ \\
\hline Juul and Skakkebæk & $12.7[1.1-19.9]$ & ARG, CLO & $15 \mathrm{mU} / \mathrm{l}$ & $61 \%(37 / 61)$ & $85 \%(121 / 142)$ \\
\hline Tillman et al. & $7.9 \pm 3.4$ & Clinical Diagn.* & & $34 \%(20 / 58)$ & $72 \%(78 / 109)$ \\
\hline Rikken et al. & $7.5 \pm 3.5$ & Not Known & $20 \mathrm{mU} / \mathrm{l}$ & $63 \%(37 / 59)$ & $84 \%(27 / 32)$ \\
\hline Mitchell et al. & $0.9-25.4$ & ITT, GLU & $13.5 \mathrm{mU} / \mathrm{l}$ & $15 \%(22 / 148)$ & $98 \%(147 / 150)$ \\
\hline Ranke et al..$^{55}$ & $6.8(1.0)$ & AITT & $10 \mathrm{ng} / \mathrm{ml}$ & $67 \%(140 / 187)$ & $50 \%(102 / 205)$ \\
\hline
\end{tabular}

Table 10: Advantages and disadvantages of criteria used in GH replacement therapy.

\begin{tabular}{|l|l|l|l|l|}
\hline & Standard dose & On body weight basis & On IGF level & \multicolumn{1}{|c|}{ On growth rate basis } \\
\hline Advantage & $\begin{array}{l}\text { Simple } \\
\text { Tried in adults }\end{array}$ & $\begin{array}{l}\text { Easy } \\
\text { Tried }\end{array}$ & $\begin{array}{l}\text { Optimal growth } \\
\text { Safe }\end{array}$ & $\begin{array}{l}\text { Most important criterion } \\
\text { Economical } \\
\text { Noninvasive }\end{array}$ \\
\hline Disadvantage & Variable results & $\begin{array}{l}\text { Disregards individual } \\
\text { GH sensitivity }\end{array}$ & $\begin{array}{l}\text { Requires laboratory } \\
\text { facilities }\end{array}$ & $\begin{array}{l}\text { Safety? } \\
\text { Requires a minimum time of } \\
6 \text { months for evaluation }\end{array}$ \\
\hline
\end{tabular}

Table 11: The targeted IGF-I Z-score values for optimal benefits from treatment

\begin{tabular}{|c|c|c|c|c|}
\hline Growth phase & $\begin{array}{l}\text { Catch-up } \\
\text { growth }\end{array}$ & $\begin{array}{l}\text { Continuity of } \\
\text { growth }\end{array}$ & Puberty & $\begin{array}{l}\text { Transition to } \\
\text { adulthood }\end{array}$ \\
\hline Aim of Treatment & $\begin{array}{l}\text { Maximum height } \\
\text { correction }\end{array}$ & Maintenance of height SDS & $\begin{array}{l}\text { Optimising final } \\
\text { height }\end{array}$ & Body composition \\
\hline $\begin{array}{l}\text { Targeted IGF-I } \\
\text { Z score }\end{array}$ & +2 to +3 SDS & -1 to +1 SDS & $\begin{array}{l}+1 \text { to }+2 \text { SDS } \\
\text { If short } \\
+2 \text { to } 3 \text { SDS }\end{array}$ & 0 to +1 SDS \\
\hline
\end{tabular}




\section{REFERENCES}

1. GH Research Society. Consensus Guidelines for the diagnosis and treatment of growth hormone deficiency in childhood and adolescence: Summary statement of the GH Research Society. J Clin Endocrinol Metab 2000;85:3990-3993. [Full Text / PDF]

2. Ranke MB. Diagnosis of Growth hormone deficiency and growth hormone stimulation tests. In: Diagnostics of endocrin function in children and adolescents. 3rd ed., Karger, Basel, 2003;107-128.

3. Dattani MT, Pringle PJ, Hindmarsh PC, Brook CGD. What is a normal stimulated growth hormone concentration? J Endocrinol 1992; 133:447-450. [Abstract]

4. Ghigo E, Bellone J, Aimaretti G, Bellone S, Loche S, Cappa M, Bartolotta E, Dammacco F, Camanni F. Reliability of provocative tests to assess growth hormone secretory status. Study in 472 normally growing children. J Clin Endocrinol Metab 1996;81:3323-3327. [Abstract]

5. Tauber M, Moulin P, Pienkowski C, Jouret B, Rochiccioli P. Growth hormone $(\mathrm{GH})$ retesting and auxological data in $131 \mathrm{GH}$-deficient patients after completion of treatment. J Clin Endocrinol Metab 1997;82:352-356. [Abstract / Full Text]

6. Juul A, Kastrup KW, Pedersen SA, Skakkebaek NE. Growth hormone (GH) provocative retesting of 108 young adults with childhood-onset GH deficiency and the diagnostic value of IGF-I and IGFBP3. J Clin Endocrinol Metab 1997;82:1195-1201. [Abstract / Full Text]

7. Granada ML, Sanmarti A, Lucas A, Salinas I, Carrascosa A, Foz M, Audi L. Assay-dependent results of immunoassayable spontaneous 24-h growth hormone secretion in short children, Acta Paediatr Scand Supp/ 1990;370:63-70. [Abstract / PDF]

8. Rogol AD, Breen TJ, Attie M for the National Cooperative growth study. National cooperative Growth study substudy II: Do growth hormone levels from serial sampling add important diagnostic information. J Pediatr 1996;128:S42-S46.

9. Marin G, Domene HM, Barnes KM, Blackwell BJ, Cassorla FG, Cutler GB. The effects of estrogen priming and puberty on the growth hormone response to standardized treadmill exercise and arginine-insulin in normal girls and boys. J Clin Endocrinol Metab 1994;79:537-541. [Abstract / PDF]

10. Lo H-C, Tsao L-Y, Hsu W-Y, Chen H-N, Yu W-K, Chi C-Y. Relation of cord serum levels of growth hormone, insulin-like growth factors, insulin-like growth factor binding proteins, leptin, and interleukin- 6 with birth weight, birth length, and head circumference interm and preterm neonates. Nutrition 2002;18:604-608. [Abstract]

11. Low LCK, Tam SYM, Kwan EYW, Tsang AMC, Karlberg J. Onset of significant GH dependence of serum IGF-I and IGF-binding protein 3 concentrations in early life. Pediatr Res 2001;50:737-742. [Abstract / Full Text / PDF]

12. Joergensen JOL, Blim WF, Moeller N, Ranke MB, Christiansen JS. Circadian patterns of serum insulin-like growth factor (IGF) II and IGF binding protein 36 in growth hormone-deficient patients and age- and sex-matched normal subjects. Acta Endocrinol 1990;123: 257-262. [Abstract]

13. Blum WF, Albertsson-Wikland K, Rosberg S, Ranke MB. Serum levels of insulin-like growth factor I (IGF-I) and IGF binding protein 3 reflect spontaneous growth hormone secretion. J Clin Endocrinol Metab 1993;76:1610-1616. [Abstract / PDF]

14. Rose SR, Ross JL, Uriarte M, Barnes KM, Cassorla FG, Cutler GB. The advantage of measuring stimulated as compared with spontaneous growth hormone levels in the diagnosis of growth hormone deficiency. N Engl J Med 1988;319:201-207. [Abstract]

15. Albertsson-Wikland K, Rosberg S, Hall K. Spontaneous secretion of growth hormone and serum levels of insulin-like growth factor I and somatomedin binding protein in children of different growth rates. In: Growth Hormone-basic and Clinical Aspects. Isaksson O, Binder C, Hall K, et al., (Eds). Elsevier, Amsterdam (Biomedical Division), 1987;163-175.

16. Saggese G, Cesaretti G, Cioni C, Cinguanta L, Ginanessi N. Relationship between plasma somatomedin C levels and 24-h spontaneous growth hormone secretion in short children. J Pediatr Endocrinol Metab 1991;4: 159-166.

17. Achermann JC, Brook CGD, Robinson ICAF, Matthews DR, Hindmarsh PC. Peak and trough growth hormone $(\mathrm{GH})$ concentrations influence growth and serum insulin like growth factor-1 (IGF-1) concentrations in short children. Clin Endocrinol (Oxf.) 1999; 50:301-308. [Abstract] 
18. Achermann JC, Hindmarsh PC, Brook CGD. The relationship between the growth hormone and insulin-like growth factor axis in long-term survivors of childhood brain tumours. Clin Endocrinol 2001;49:639-645. [Abstract / Full Text / PDF]

19. Juul A, Moller S, Mosfeldt-Laursen E, Rasmussen MH, Scheike T, Pedersen SA, Kastrup KW, Yu H, Mistry J, Rasmussen S, Müller J, Henriksen J, Skakkebaek NE. The acid-labile subunit of human ternary insulin-like growth factor binding protein complex in serum: hepatosplanchnic release, diurnal variation, circulating concentrations in healthy subjects, and diagnostic use in patients with growth hormone deficiency. J Clin Endocrinol Metab 1998;83:4408-4415. [Abstract / Full Text / PDF]

20. Giudice LC, de Zegher F, Gargosky SE, Dsupin BA, de las Fuentes L, Crystal RA, Hintz RL, Rosenfeld RG. Insulin-like growth factors and their binding proteins in the term and preterm human fetus and neonate with normal and extremes of intrauterine growth. J Clin Endocrinol Metab 1995;80: 15481555. [Abstract / PDF]

21. Yang SW, Yu JS. Relationship of insulin-like growth factor-I, insulin-like growth factor binding protein-3, insulin, growth hormone in cord blood and maternal factors with birth height and birth weight. Pediatr Int 2000;42:31-36. [Abstract / Full Text / PDF]

22. Clemmons DR, Underwood LE. Nutritional regulation of IGF-I and IGF binding proteins. Annu Rev Nutr 1991;11:393-412. [Abstract / PDF]

23. Juul A. Serum levels of insulin-like growth factor I and its binding proteins in health and disease. Growth Horm IGF Res 2003;13:113-170.

24. Juul A, Bang P, Hertel NT, Main K, Dalgaard P, Jorgensen K, Müller J, Hall K, Skakkebaek NE. Serum insulin-like growth factor-I in 1030 healthy children, adolescents, and adults: relation to age, sex, stage of puberty, testicular size, and body mass index. J Clin Endocrinol Metab 1994;78:744-752. [Abstract / PDF]

25. Cara JF, Rosenfield RL, Furlanetto RW. A longitudinal study of the relationship of plasma somatomedin-C concentration to the pubertal growth spurt. Am J Dis Child 1987;141:562-564. [Abstract / Full Text / PDF]

26. Rosenfield RI, Furlanetto R, Bock D. Relationship of somatomedin-C concentrations to pubertal changes. J Pediatr 1983;103:723-728. [Abstract / PDF]

27. Juul A, Dalgaard P, Blum WF, Bang P, Hall K, Michaelsen KF, Müller J, Skakkebaek NE. Serum levels of insulin-like growth factor (IGF)- binding protein-3 (IGFBP-3) in healthy infants, children, and adolescents: the relation to IGF-I, IGF-II, IGFBP-1, IGFBP-2, age, sex, body mass index, and pubertal maturation. J Clin Endocrinol Metab 1995;80:2534-2542. [Abstract / PDF]

28. Bereket A, Turan S, Omar A, Berber M, Ozen A, Akbenlioğlu C, Haklar G. Serum IGF-I and IGFBP-3 levels of Turkish children during childhood and adolescence: establishment of reference ranges with emphasis on puberty. Horm Res 2006 ;65: 96-105. [Abstract / Full Text / PDF]

29. Turan S, Bereket B, Furman A, Omar A, Berber M, Ozen A, Akbenlioglu C, Haklar G. The effect of economic status on height, insulin-like growth factor (IGF)-I and IGF binding protein-3 concentrations in healthy Turkish children. Eur J Clin Nutr 2007;61: 752-758. [Abstract / Full Text / PDF]

30. Rosenfeld RG, Wilson DM, Lee PDK, Hintz RL. Insulin-like growth factors I and II in evaluation of growth retardation. J Pediatr 1986;109:428-433. [Abstract]

31. Juul A, Skakkebaek NE. Prediction of the outcome of growth hormone provocative testing in short children by measurement of serum levels of insulin-like growth factor I and insulin-like growth factor binding protein-3. J Pediatr 1997;130:197-204. [Abstract / Full Text / PDF]

32. Rikken B, van Doorn J, Ringeling A, van den Brande JL, Massa G, Wit JM. Plasma levels of insulinlike growth factor (IGF)-I, IGF-II and IGF-binding protein-3 in the evaluation of childhood growth hormone deficiency. Horm Res 1998;50:166-176. [Abstract / Full Text / PDF]

33. Ranke MB, Schweizer R, Elmlinger MW, Weber K, Binder G, Schwarze CP, Wollmann HA. Significance of basal IGF-I, IGFBP-3 and IGFBP-2 measurements in the diagnostics of short stature in children. Horm Res 2000;54: 60-68. [Abstract / Full Text / PDF]

34. Nunez SB, Municchi G, Barnes KM, Rose SR. Insulin-like growth factor I (IGF-I) and IGF-binding protein-3 concentrations compared to stimulated and night growth hormone in the evaluation of short children-a clinical research center study. J Clin Endocrinol Metab 1996;81:1927-1932. [Abstract / PDF] 
35. Smith WJ, Nam TJ, Underwood LE, Busby WH, Celnicker A, Clemmons DR. Use of insulin-like growth factor-binding protein-2 (IGFBP-2), IGFBP-3, and IGF-I for assessing growth hormone status in short children. J Clin Endocrinol Metab 1993;77:1294-1299. [Abstract / PDF]

36. Cianfarani S, Boemi S, Spagnoli A, Cappa M, Argiro G, Vaccaro F, Manca Bitti ML, Boscherini B. Is IGF binding protein-3 assessment helpful for the diagnosis of $\mathrm{GH}$ deficiency? Clin Endocrinol (Oxf.) 1995;43:43-47. [Abstract]

37. Tillmann V, Buckler JM, Kibirige MS, Price DA, Shalet SM, Wales JK, Addison MG, Gill MS, Whatmore AJ, Clayton PE. Biochemical tests in the diagnosis of childhood growth hormone deficiency. J Clin Endocrinol Metab 1997;82:531-535. [Abstract]

38. Lee PD, Wilson DM, Rountree L, Hintz RL, Rosenfeld RG. Efficacy of insulin-like growth factor I levels in predicting the response to provocative growth hormone testing. Pediatr Res 1990;27:45-51. [Abstract / PDF]

39. Hasegawa Y, Hasegawa T, Takada M, Tsuchiya Y. Plasma free insulin-like growth factor I concentrations in growth hormone deficiency in children and adolescents. Eur J Endocrinol 1996;134:184-189. [Abstract]

40. Bussieres L, Souberbielle JC, Pinto G, Adan L, Noel M, Brauner R. The use of insulin-like growth factor 1 reference values for the diagnosis of growth hormone deficiency in prepubertal children. Clin Endocrinol (Oxf) 2000;52:735-739. [Abstract]

41. Blum WF, Ranke MB, Kietzmann K, Gauggel E, Zeisel HJ, Bierich JR. A specific radioimmunoassay for the growth hormone (GH)-dependent somatomedin-binding protein: its use for diagnosis of $\mathrm{GH}$ deficiency. J Clin Endocrinol Metab 1990;70:1292-1298. [Abstract]

42. Mitchell H, Dattani MT, Nanduri V, Hindmarsh PC, Preece MA, Brook CGD. Failure of IGF-I and IGFBP-3 to diagnose growth hormone insufficiency. Arch Dis Child 1999;80:443-447. [Abstract / Full Text / PDF]

43. Hasegawa Y, Hasegawa T, Aso T, Kotoh S, Nose O, Ohyama Y, Araki K, Tanaka T, Saisyo S, Yokoya S. Clinical utility of insulin-like growth factor binding protein-3 in the evaluation and treatment of short children with suspected growth hormone deficiency. Eur J Endocrinol 1994;131:27-32.

44. Karachaliou F, Stamoyannou L, Maravelias K, Bartsocas CS, Koutselinis A. Serum levels of IGFBP-3: usefulness in diagnosis of GH deficiency and relationship to measurements of GH secretion in children. J Pediatr Endocrinol 1996;9:169-174. [Abstract]

45. Cohen P, Bright GM, Rogol AD, Kappelgaard AM, Rosenfeld RG; American Norditropin Clinical Trials Group. Effects of dose and gender on the growth and growth factor response to $\mathrm{GH}$ in GH-deficient children: implications for efficacy and safety. J Clin Endocrinol Metab 2002;87:90-98. [Abstract / Full Text / PDF] 